\title{
Evolution of thermal properties of natural rubber nanocomposites functionalized by nickel-zinc ferrite and potassium strontium niobate nanopowders
}

\author{
Felipe Silva Bellucci ${ }^{1,2}$ - Fabricio César Lobatode Almeida ${ }^{3}$. \\ Deuber Lincon da Silva Agostini ${ }^{4} \cdot$ Marcos Augusto Lima Nobre ${ }^{4}$. \\ Amarildo Tabone Paschoalini ${ }^{1} \cdot$ Aldo Eloizo Job $^{4}$
}

Received: 10 May 2015/Accepted: 30 May 2016/Published online: 20 June 2016

(C) Akadémiai Kiadó, Budapest, Hungary 2016

\begin{abstract}
Several composites and nanocomposites based on a polymeric matrix and ceramic fillers are being pursued for use as multifunctional and innovative materials. Nevertheless, there is a series of challenges to be solved in this area such as the understanding of the role of interfaces and the synergy between matrix and fillers. In this work, vulcanized natural rubber nanocomposites were prepared with different concentrations of two kinds of ceramic nanoparticles, potassium strontium niobate $\left(\mathrm{KSr}_{2} \mathrm{Nb}_{5} \mathrm{O}_{15}\right.$ or $\left.\mathrm{KSN}\right)$ and nickel-zinc ferrite $\left(\mathrm{Ni}_{0.5} \mathrm{Zn}_{0.5} \mathrm{Fe}_{2} \mathrm{O}_{4}\right.$ or NZF), synthesized by a chemical method known as the modified polyol method. Morphological and thermal characterizations were carried out by AFM, TG/DTG, TG/FTIR and DSC. The thermal properties of nanocomposites were compared and discussed as functions of concentration, type and surface of nanoparticles. The results obtained suggest that the base concentration for both types of nanoparticles inside the polymer matrix volume greatly adds to the increase in thermal stability up to $11 \%$ and the glass transition temperature up to $10{ }^{\circ} \mathrm{C}$. A similar evolution for the glass transition temperature $\left(T_{\mathrm{g}}\right)$, thermal stability temperature $\left(T_{\mathrm{S}}\right)$ and dielectric permittivity $\left(\varepsilon^{\prime}\right)$ was identified,
\end{abstract}

Aldo Eloizo Job

job@fct.unesp.br

1 FEIS-Faculdade de Engenharia de Ilha Solteira, UNESPUniv Estadual Paulista, CEP 15385-000 Ilha Solteira, SP, Brazil

2 Ministério da Ciência, Tecnologia e Inovação-MCTI, CEP 70067-900 Brasília, DF, Brazil

3 Department of Biosystem Engineering, UNESP_Univ Estadual Paulista, CEP 17602-496 Tupã, SP, Brazil

4 FCT_Faculdade de Ciências e Tecnologia, UNESP_Univ Estadual Paulista, C.P. 467 Presidente Prudente, SP, Brazil suggesting that these phenomena are mainly dominated by the same mechanisms. These results point to the possibility for the thermal parameter modulation in magnetic and ferroelectric nanocomposites by means of a suitable control of concentration and properties of the KSN and NZF nanoparticles.

Keywords Nickel-zinc ferrite · Potassium strontium niobate Functionalized nanocomposites $\cdot$ Thermal properties · Thermal stability · Glass transition temperature

\section{Introduction}

In general, materials of sizes ranging from $1 \times 10^{-9}$ and $100 \times 10^{-9} \mathrm{~m}$ are called nanomaterials regardless of their nature, whether ceramic, polymer, metal or composite. When a material has dimensions in the nanometric scale, its surface and book properties are, in general, differentiated in relation to material properties on a higher dimensional scale. One reason for the differentiated properties presented by the nanoscale is the distinct surface/volume proportion or aspect ratio that is not linear for different dimensional scales $[1,2]$. In general, the choice of polymer as a matrix or continuous phase is preferable since most have appreciable thermal and mechanical properties, and the natural rubber is a desirable candidate owing to its distinctive ability to incorporate large amounts, up to $600 \mathrm{phr}$, of solid and inert particles, maintaining acceptable mechanical properties [3, 4].

Some typical examples of polymer/ceramic composites and nanocomposites of technological interest are: (1) composites formed by paraelectric particles of $\mathrm{Ba}_{0.6} \mathrm{Sr}_{0.4} \mathrm{TiO}_{3}$ with different size and particle concentration dispersed in a low-loss dielectric matrix that can be applied in microwave 
devices for wireless telecommunications [5]; (2) hybrid composites based on ferroelectric and piezoelectric crystal particles, randomly distributed in a polymer matrix of epoxy resin represent a novel class of materials with potential to be applied as integrated capacitors, acoustic emission sensors, smart skins and leakage current controllers [6]; (3) carbon nanotubes and carbon black embedded in thermoplastic and elastomeric matrices producing significant mechanical, electric, anti-aging and thermal improvements in the composites and nanocomposites making them suitable for production of automobile pieces, footwear and use in pneumatic industries [7, 8]; and (4) magnetic composite and nanocomposites based on ferrites, iron and nickel oxides in concentrations of up to $600 \mathrm{phr}$ dispersed in polymeric matrices that can be used as flexible microwave absorbers, in wireless data communication, in local area network, satellite television and heating systems $[3,9,10]$.

In the last few years, traditionally, niobates with tetragonal tungsten bronze structure (TTB) as $\mathrm{KSr}_{2} \mathrm{Nb}_{5} \mathrm{O}_{15}$ (KSN) have proved to be of technological interest principally due to the high anisotropy of the crystalline structure and ferroelectric properties with great potential for applications such as sensor devices, actuators, memories, filters and capacitors (wireless communication) [11, 12]. Nickelzinc ferrites are typical polycation oxides exhibiting an inverse spinel structure with a complex cation distribution in the crystalline structure. Spinels based on Fe cations such as the $\mathrm{Ni}-\mathrm{Zn}$ ferrite oxides with stoichiometry $\mathrm{Ni}_{0.5-}$ $\mathrm{Zn}_{0.5} \mathrm{Fe}_{2} \mathrm{O}_{4}$ (NZF) show a growing potential for applications such as functional ferrofluid, electromagnetic wave absorption and cancer treatment and core transformers [13]. These two kinds of nanoparticles can be dispersed in vulcanized natural rubber matrices adding some of their properties to the elastomeric matrix. Ferrite natural rubber composites are more common, as cited above, than niobate natural rubber composites, and the structural [14], mechanical [15] and magnetic [16] properties of these composites were recently reported by our group. However, reports on the thermal properties of natural rubber nanocomposites prepared with ferroelectric and magnetic nanoparticles synthesized by a chemical synthesis named the Polyol Method are not very abundant in scientific literature.

In this paper, natural rubber nanocomposites with different concentrations of $\mathrm{KSr}_{2} \mathrm{Nb}_{5} \mathrm{O}_{15}$ niobato (NR/KSN) and $\mathrm{Ni}_{0.5} \mathrm{Zn}_{0.5} \mathrm{Fe}_{2} \mathrm{O}_{4}$ ferrite (NR/NZF) nanopowders were prepared by melt blending and compression molding. Morphological and thermal characterizations were carried out by AFM, TG/DTG, TG/FTIR and DSC. A comparison between the thermal properties of nanocomposites was made, and further discussion as a function of concentration, type and surface properties of nanoparticles was carried out.

\section{Materials and methods}

\section{Preparation of the KSN and NZF nanoparticles}

Nickel-zinc ferrite $\left(\mathrm{Ni}_{0.5} \mathrm{Zn}_{0.5} \mathrm{Fe}_{2} \mathrm{O}_{4}\right)$ and potassium strontium niobate nanopowders $\left(\mathrm{KSr}_{2} \mathrm{Nb}_{5} \mathrm{O}_{15}\right)$ were prepared by a chemical route known as the modified polyol method (MPM) [17], a low cost and low step number technique directed at the synthesis of a significant batch of particles. For the NZF nanoparticles, we used nickel oxide $\left(\mathrm{Ni}_{2} \mathrm{O}_{3}\right.$, molecular weight: $165.36 \mathrm{~g} \mathrm{~mol}^{-1}$, purity: analytical purity (A.P.), origin: Vetec), zinc oxide $\left(\mathrm{ZnO}, 81.41 \mathrm{~g} \mathrm{~mol}^{-1}\right.$, A.P., Vetec), iron oxide $\left(\mathrm{Fe}_{2} \mathrm{O}_{3}, 159.69 \mathrm{~g} \mathrm{~mol}^{-1}\right.$, A.P., Vetec), ethylene glycol $\left(\mathrm{C}_{2} \mathrm{H}_{4}(\mathrm{OH})_{2}, 62.06 \mathrm{~g} \mathrm{~mol}^{-1}\right.$, A.P., Fmaia) and nitric acid $\left(\mathrm{HNO}_{3}, 63.01 \mathrm{~g} \mathrm{~mol}^{-1}, 65 \%\right.$, Nuclear). For the KSN nanoparticles, we used strontium carbonate $\left(\mathrm{SrCO}_{3}\right.$, $147.63 \mathrm{~g} \mathrm{~mol}^{-1}$, A. P., Vetec), potassium carbonate $\left(\mathrm{K}_{2} \mathrm{CO}_{3}, 138.21 \mathrm{~g} \mathrm{~mol}^{-1}\right.$, A. P., Vetec), niobium complex $\left(\mathrm{NH}_{4} \mathrm{H}_{2}\left[\mathrm{NbO}\left(\mathrm{C}_{2} \mathrm{O}_{4}\right)_{3}\right] \cdot 3 \mathrm{H}_{2} \mathrm{O}, 460.92 \mathrm{~g} \mathrm{~mol}^{-1}\right.$, A. P., CBMM-Araxá), ethylene glycol and nitric acid.

For the two ceramic phases prepared by the MPM chemical route, the starting reagents, mentioned previously and in an appropriate ratio, were mixed in thoroughly according to their stoichiometry in a high energy ball milling for $10 \mathrm{~min}$, at room temperature and using micrometric zirconia balls only in order to obtain a homogeny mixing of oxides. The pre-calcination and calcination of both samples were done using a chamber-type oven, brand INTI. For the $\mathrm{NZF}$, pre-annealing was performed at a final temperature of $300{ }^{\circ} \mathrm{C}$ at a heating rate of $10{ }^{\circ} \mathrm{C} \mathrm{min}^{-1}$, flow rate $300 \mathrm{~mL} \mathrm{~min}{ }^{-1}$ of $\mathrm{N}_{2}$ and soaking for an hour at the final temperature. The calcinations of the NZF were performed at a final temperature of $450{ }^{\circ} \mathrm{C}$ and a heating rate of $5{ }^{\circ} \mathrm{C} \min ^{-1}$, flow $7 \mathrm{~L} \mathrm{~min}{ }^{-1}$ and kept for $3 \mathrm{~h}$ at the final temperature. Cooling was attained with natural air flow. For the KSN, pre-annealing was performed at a final temperature of $300{ }^{\circ} \mathrm{C}$ at a heating rate of $10{ }^{\circ} \mathrm{C} \mathrm{min}^{-1}$, flow of $500 \mathrm{~mL} \mathrm{~min}^{-1}$ of $\mathrm{N}_{2}$ and kept for $1 \mathrm{~h}$ at the final temperature. Calcination was done at a final temperature of $450{ }^{\circ} \mathrm{C}$ and a heating rate of $5{ }^{\circ} \mathrm{C} \mathrm{min}{ }^{-1}$, flow of $150 \mathrm{~mL} \mathrm{~min}{ }^{-1}$ of $\mathrm{O}_{2}$ and kept for $2 \mathrm{~h}$ at the final temperature.

\section{Preparation of the NR/KSN and NR/NZF nanocomposites}

Dry natural rubber was used for the preparation of the nanocomposites (cis-1,4-polyisoprene) of the commercial variety CCB (Crepe Claro Brasileiro-CCB), financed by the DLP Industria e Comércio de Borracha e Artefatos ${ }^{(R)}$ in the city of Poloni/SP. This rubber is obtained in processing plants by the coagulation of latex from the Hevea brasiliensis species, clones RRIM 600. 
The processing of the samples was carried out in an internal mixer of the Haake brand, model Rheodrive 5000. First, a mixture of natural rubber was made with both kinds of nanoparticles $(0,1,3,5,10,20$ and $50 \mathrm{phr})$ and an activation system consisting of $4 \mathrm{phr}$ of zinc oxide $(\mathrm{ZnO}$, $81.41 \mathrm{~g} \mathrm{~mol}^{-1}$, A. P., Vetec) and $3 \mathrm{phr}$ of stearic acid $\left(\mathrm{CH}_{3}\left(\mathrm{CH}_{2}\right)_{16} \mathrm{COOH}, 284.47 \mathrm{~g} \mathrm{~mol}^{-1}\right.$, A. P., Vetec). The processing conditions were as follows: the temperature of the blades was $40{ }^{\circ} \mathrm{C}$ with a rotation speed of $60 \mathrm{rpm}$ and a mixing time of $5 \mathrm{~min} .2 \mathrm{phr}$ of sulfur $\left(\mathrm{S}_{8}, 240.48 \mathrm{~g} \mathrm{~mol}^{-1}\right.$, A. P., Nuclear) and $1 \mathrm{phr}$ of 2-mercaptobenzothiazol $\left(\mathrm{S}_{2} \mathrm{NC}_{7} \mathrm{H}_{5}, 167.24 \mathrm{~g} \mathrm{~mol}^{-1}\right.$, A. P., Polyorganic) were added to all samples in the same processing conditions $24 \mathrm{~h}$ after the first mix. The compositions of the NR, NR/KSN and NR/NZF nanocomposites are listed in Table 1. After undergoing two mixing processes and as is common practice for natural rubber [18], the formulations were compressed and thermos molded at $150{ }^{\circ} \mathrm{C}$ with a closing pressure of $2.5 \mathrm{MPa}$ in a pneumatic press for the optimum cure time, well known $t_{90}$. The $t_{90}$ was determined using a torque rheometer, type Teamter, Team brand, being on average equal to $8^{\prime} 28^{\prime \prime}$ for the NR/KSN and $8^{\prime} 30^{\prime \prime}$ for the NR/NZF nanocomposites. The preparation process for the nanocomposites is shown in Fig. 1.

\section{Characterization of the NR/KSN and NR/NZF nanocomposites}

\section{AFM assays}

The structural and morphological characterizations at room temperature of the vulcanized natural rubber NR, NR/KSN and NR/NZF nanocomposites were carried out by atomic-force

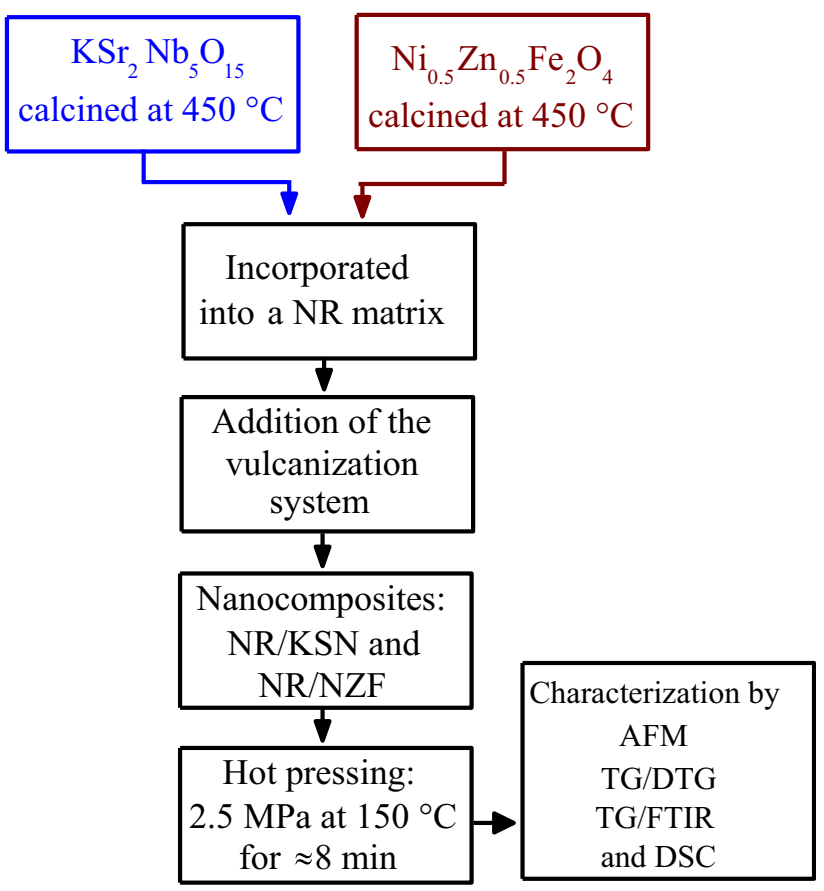

Fig. 1 Flow diagram for the preparation process of vulcanized natural rubber and NR/KSN and NR/NZF nanocomposites

microscopy (AFM) using an AFM/STM microscope, model nanoscope, in the contact mode on the nanocomposites' surface. The public-domain software used to generate the threedimensional projection of the sample surface from the AFM images in the mode height was the Gwyddion ${ }^{\circledR}$ version 2.29.

\section{TG/DTG, TG-FTIR and DSC assays}

The thermal characterization of the vulcanized natural rubber NR, NR/KSN and NR/NZF was carried out by

Table 1 Compositions of the NR, NR/KSN and NR/NZF nanocomposites

\begin{tabular}{|c|c|c|c|c|c|c|}
\hline Name & Natural rubber & Zinc oxide & Stearic acid & Sulfur & $\begin{array}{l}\text { Mercapto- } \\
\text { benzotiazol }\end{array}$ & $\begin{array}{l}\text { Nanoparticles KSN or } \\
\text { NZF }\end{array}$ \\
\hline NR & $\begin{array}{r}100 \mathrm{phr}^{*} \text { or } \\
(90.9 \mathrm{w} \%)\end{array}$ & $\begin{array}{l}4 \mathrm{phr} \text { or } \\
\quad(3.6 \mathrm{w} \%)\end{array}$ & $\begin{array}{l}3 \text { phr or } \\
(2.7 \mathrm{w} \%)\end{array}$ & $\begin{array}{l}2 \mathrm{phr} \text { or } \\
(1.8 \mathrm{w} \%)\end{array}$ & $\begin{array}{l}1 \mathrm{phr} \text { or } \\
(0.9 \mathrm{w} \%)\end{array}$ & - \\
\hline $\begin{array}{l}\text { NR/KSN or NR/NZF } \\
1 \mathrm{phr}\end{array}$ & $\begin{array}{l}100 \mathrm{phr} \text { or } \\
(90.1 \mathrm{w} \%)\end{array}$ & $\begin{array}{l}4 \mathrm{phr} \text { or } \\
(3.6 \mathrm{w} \%)\end{array}$ & $\begin{array}{l}3 \text { phr or } \\
(2.7 \mathrm{w} \%)\end{array}$ & $\begin{array}{l}2 \mathrm{phr} \text { or } \\
(1.8 \mathrm{w} \%)\end{array}$ & $\begin{array}{l}1 \mathrm{phr} \text { or } \\
(0.9 \mathrm{w} \%)\end{array}$ & $1 \mathrm{phr}$ or $(0.9 \mathrm{w} \%)$ \\
\hline $\begin{array}{l}\text { NR/KSN or NR/NZF } \\
3 \mathrm{phr}\end{array}$ & $\begin{array}{l}100 \mathrm{phr} \text { or } \\
(88.5 \mathrm{w} \%)\end{array}$ & $\begin{array}{l}4 \mathrm{phr} \text { or } \\
\quad(3.5 \mathrm{w} \%)\end{array}$ & $\begin{array}{l}3 \mathrm{phr} \text { or } \\
(2.7 \mathrm{w} \%)\end{array}$ & $\begin{array}{l}2 \mathrm{phr} \text { or } \\
(1.8 \mathrm{w} \%)\end{array}$ & $\begin{array}{l}1 \mathrm{phr} \text { or } \\
(0.9 \mathrm{w} \%)\end{array}$ & 3 phr or $(2.7 \mathrm{w} \%)$ \\
\hline $\begin{array}{l}\text { NR/KSN or NR/NZF } \\
5 \mathrm{phr}\end{array}$ & $\begin{array}{l}100 \mathrm{phr} \text { or } \\
(87.0 \mathrm{w} \%)\end{array}$ & $\begin{array}{l}4 \mathrm{phr} \text { or } \\
(3.5 \mathrm{w} \%)\end{array}$ & $\begin{array}{l}3 \text { phr or } \\
(2.6 \mathrm{w} \%)\end{array}$ & $\begin{array}{l}2 \mathrm{phr} \text { or } \\
(1.7 \mathrm{w} \%)\end{array}$ & $\begin{array}{l}1 \mathrm{phr} \text { or } \\
(0.9 \mathrm{w} \%)\end{array}$ & $5 \mathrm{phr}$ or $(4.4 \mathrm{w} \%)$ \\
\hline $\begin{array}{l}\text { NR/KSN or NR/NZF } \\
10 \mathrm{phr}\end{array}$ & $\begin{array}{l}100 \mathrm{phr} \text { or } \\
(83.3 \mathrm{w} \%)\end{array}$ & $\begin{array}{l}4 \text { phr or } \\
\quad(3.3 \mathrm{w} \%)\end{array}$ & $\begin{array}{l}3 \mathrm{phr} \text { or } \\
(2.5 \mathrm{w} \%)\end{array}$ & $\begin{array}{l}2 \mathrm{phr} \text { or } \\
\quad(1.7 \mathrm{w} \%)\end{array}$ & $\begin{array}{l}1 \mathrm{phr} \text { or } \\
(0.8 \mathrm{w} \%)\end{array}$ & $10 \mathrm{phr}$ or $(8.3 \mathrm{w} \%)$ \\
\hline $\begin{array}{l}\text { NR/KSN or NR/NZF } \\
20 \mathrm{phr}\end{array}$ & $\begin{array}{l}100 \mathrm{phr} \text { or } \\
(76.9 \mathrm{w} \%)\end{array}$ & $\begin{array}{l}4 \text { phr or } \\
\quad(3.1 \mathrm{w} \%)\end{array}$ & $\begin{array}{l}3 \text { phr or } \\
(2.3 \mathrm{w} \%)\end{array}$ & $\begin{array}{l}2 \text { phr or } \\
(1.5 \mathrm{w} \%)\end{array}$ & $\begin{array}{l}1 \mathrm{phr} \text { or } \\
(0.8 \mathrm{w} \%)\end{array}$ & $20 \mathrm{phr}$ or $(15.4 \mathrm{w} \%)$ \\
\hline $\begin{array}{l}\text { NR/KSN or NR/NZF } \\
50 \mathrm{phr}\end{array}$ & $\begin{array}{l}100 \mathrm{phr} \text { or } \\
(62.5 \mathrm{w} \%)\end{array}$ & $\begin{array}{l}4 \mathrm{phr} \text { or } \\
(2.5 \mathrm{w} \%)\end{array}$ & $\begin{array}{l}3 \text { phr or } \\
(1.9 \mathrm{w} \%)\end{array}$ & $\begin{array}{l}2 \mathrm{phr} \text { or } \\
(1.3 \mathrm{w} \%)\end{array}$ & $\begin{array}{l}1 \mathrm{phr} \text { or } \\
(0.6 \mathrm{w} \%)\end{array}$ & $50 \mathrm{phr}$ or $(31.3 \mathrm{w} \%)$ \\
\hline
\end{tabular}

${ }^{a}$ Parts per hundred of rubber 
thermogravimetric analysis (TG) coupled to Fourier transform infrared spectroscopy (FTIR) and differential scanning calorimetry (DSC). Thermogravimetric analysis was obtained in a Mettler-Toledo, model SDTA851e and in a Netzsch, model 209 , between 50 and $850{ }^{\circ} \mathrm{C}$, at a heating rate of $20^{\circ} \mathrm{C} \mathrm{min}^{-1}$ in an inert atmosphere $\left(\mathrm{N}_{2}\right)$. The sample holder Bruker model Vector 22 and a detector DTGS with an accuracy of $4 \mathrm{~cm}^{-1}$ and 32 scans were used. Approximately $10 \mathrm{mg}$ of each sample was used. The differential scanning calorimetry analysis was obtained in a Mettler-Toledo, model DSC822, between -100 and $75{ }^{\circ} \mathrm{C}$, at a heating rate of $10{ }^{\circ} \mathrm{C} \mathrm{min}{ }^{-1}$ in an inert atmosphere $\left(\mathrm{N}_{2}\right)$. An aluminum crucible was used with $10 \mathrm{mg}$ of the sample, and the glass transition temperature $\left(T_{\mathrm{g}}\right)$ was calculated as the point of inflection in the step change observed in the heat flow curve.

\section{Dielectric assays}

The dielectric measurements were carried out by impedance spectroscopy at $100 \mathrm{kHz}$, using a Novocontrol model $\alpha$-analyser controlled by a personal computer. The nominal applied voltage was $500 \mathrm{mV}$. Samples with a diameter of approximately $10 \mathrm{~mm}$ and a thickness of about $0.50 \mathrm{~mm}$ were used and compressed by $475 \mathrm{~Pa}$. The surfaces of the samples were first painted with a thin layer of high-purity silver paint in order to ensure good contact during the electrical measurements.

\section{Results and discussions}

Atomic-force microscopy (AFM) is a technique designed primarily for the topographic mapping of the sample surface, and it provides information about the surface topography, molecular ordering and defects, valleys and hills on the molecular level, as well as roughness of the samples. Figure 2 shows images obtained directly from the surface of the samples (left images) and their respective three-dimensional projection (right images) by the technique of atomic-force microscopy on the pure vulcanized natural rubber and the ferroelectric and magnetic nanocomposites formed by the addition of $10 \mathrm{phr}$. Table 2 lists values of the parameter surface roughness of the ferroelectric nanocomposites as a function of the nanoparticle concentration. According to Fig. 2 and knowing that the nanocomposites were thermoconformed at the optimum cure time $\left(t_{90}\right)$ ensuring that a minimum of $90 \%$ of cure occurred, it is possible to observe a good surface homogeneity for vulcanized natural rubber and for nanocomposites, indicating that the vulcanization system and the manufacturing parameters used were appropriate. As we can see in Table 2, significant differences for surface roughness were identified for the NR/KSN and NZF/NR for a low amount of nanometric fillers, for example, less than $5 \mathrm{phr}$, were used, indicating that phenomena such as stress-induced crystallization may be dominant [19]. The maximum value of the surface roughness was $0.83 \mathrm{~nm}$ for the NR/KSN-3phr, while the minimum value was $0.43 \mathrm{~nm}$ for the NR/NZF-20phr. It seems that the differences of surface roughness observed between the magnetic and ferroelectric nanocomposites can be correlated with: (1) interface filler/matrix phenomena generating changes in the folding of the polymer chains; (2) the different thermal diffusion coefficient due to the inclusion of a ceramic phase; and (3) directional anisotropy for the mobility of the polymer chains [19].

Thermogravimetric (TG) and derivative thermogravimetry (DTG) analyses are useful thermoanalytic techniques commonly used to determine thermal parameters as thermal degradation temperature, thermal stability temperature and temperature of maximum mass loss. The TG and DTG analyses for both NR/KSN (a) and NR/NZF (b) for the nanocomposites as a function of the concentration of nanoparticles are shown in Fig. 3. According to Fig. 3, all the nanocomposites investigated show a similar evolution of the mass loss as a function of the temperature, indicating that the elastomeric properties of the vulcanized natural rubber (NR) were maintained. This fact suggests that the incorporation of nanoparticles, independent of their concentration, does not significantly alter the structure of the polymeric matrix. Furthermore, this is a suitable quality of this kind of systems because they are maintaining the main rubber characteristics and incorporating the nanoparticles properties, and at the end, fictionalized materials were obtained. Apparently, only one fast exothermic mass loss between 300 and $490{ }^{\circ} \mathrm{C}$ was observed, which is assigned to the thermal degradation of poli-isoprene, dipentene and p-menthene. Different areas under the curve and consequently energy reactions were indentified due to the distinct proportion of natural rubber in each sample. In addition, it is possible to observe a small shoulder with low intensity at around $438{ }^{\circ} \mathrm{C}$ for all materials investigated. This shoulder is indicated by blue arrows, and it can be associated with different degradation temperatures for constituents of natural rubber. A small and endothermic peak would be expected in the samples with NZF nanopowders at temperatures of between 300 and $500{ }^{\circ} \mathrm{C}$, and this peak is signed to the Curie transition in $\mathrm{Ni}-\mathrm{Zn}$ ferrites. In bulk-synthesized NiZn-ferrites, the Curie transitions are at around $490{ }^{\circ} \mathrm{C}$, but with the decrease in particle size, it is known that the temperature of this phase transition decreases as well [20]. Unfortunately, because of the high intensity of the degradation of the isoprenic chain, it is not possible to identify the Curie transition in NZF powders. The residual mass is composed of ceramic 
(a)
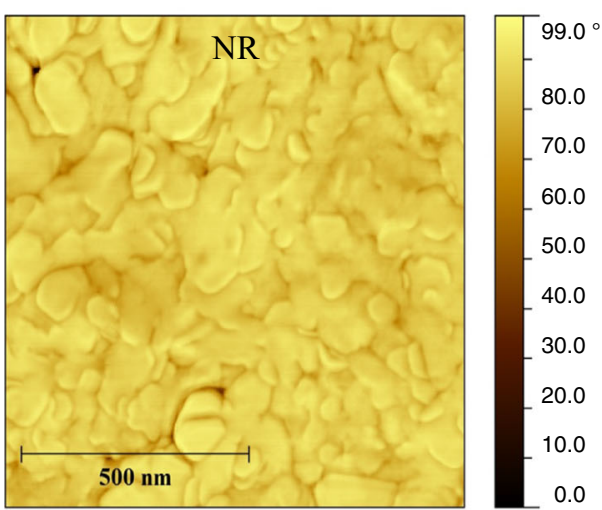

(b)

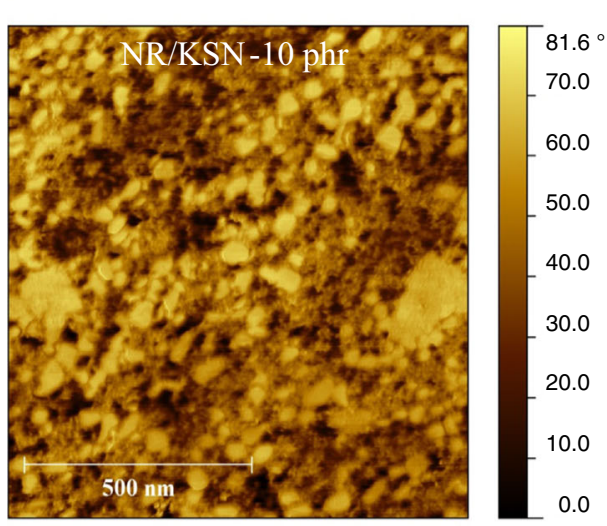

(c)

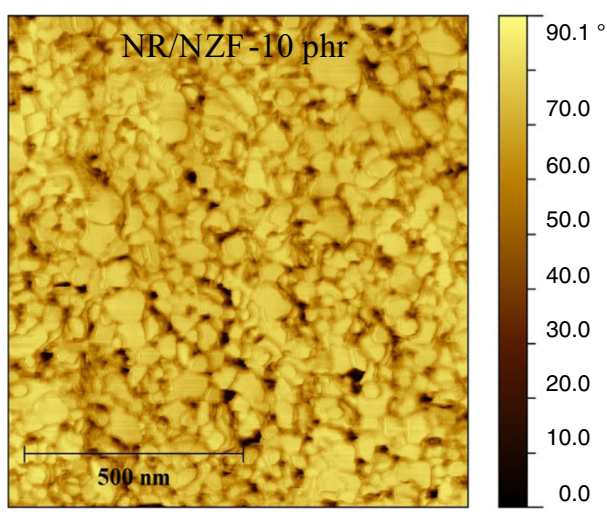

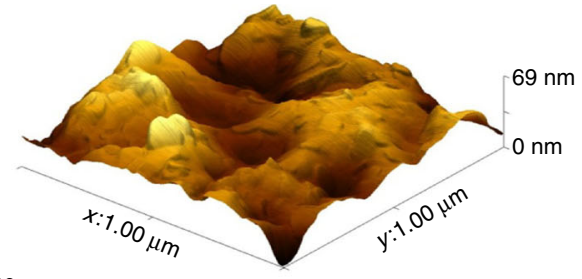
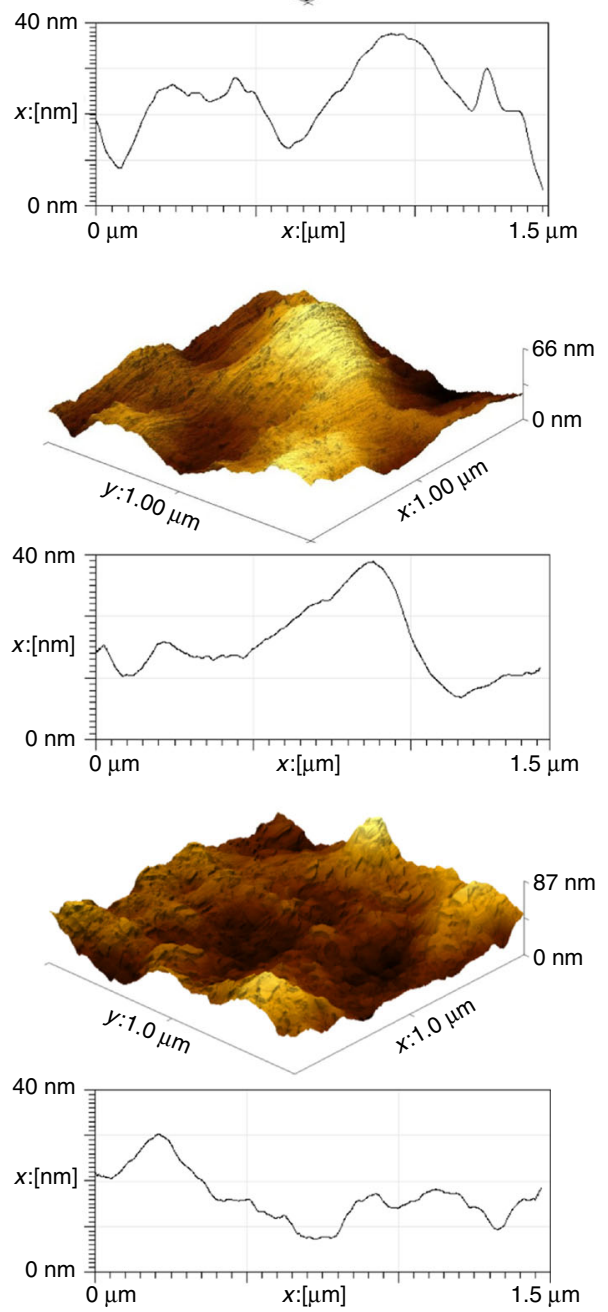

Fig. 2 Images obtained using the technique of atomic-force microscopy to: vulcanized natural rubber NR (a), ferroelectric nanocomposites NR/KSN (b) and magnetic nanocomposites NR/NZF (c) both with $10 \mathrm{phr}$ of nanoparticles

materials, and the values are in concordance with the amount of nanoparticle incorporated into NR matrix, see details plotted in Fig. 3a, c. The experimental mass losses are in good agreement with the theoretical expectation, i.e., $\mathrm{R}^{2}$ approximately 1 . As expected, the evolution of residual mass as a function of the nanoparticle concentration is linear with an angle of inclination slightly less than $45^{\circ}$, in fact 42 and $44^{\circ}$, indicating that there is an interaction between fillers and matrix, but this interaction is weak and formed only by physical interactions. For the NR/NZF nanocomposites, Fig. 3c, d, the beginning of a reaction can be noted at around $730{ }^{\circ} \mathrm{C}$; see the red squares. This reaction is related mainly to iron oxide changing in its polymorphic forms [21].

The thermal stability temperature $\left(T_{\mathrm{S}}\right)$ is a thermal parameter widely used in the engineering area indicating the maximum working temperature before starting the thermal degradation processes. Figure 4 shows the evolution of $T_{\mathrm{S}}$; in this paper, $T_{\mathrm{S}}$ was measured as the temperature at which the sample loses exactly $1 \%$ of its mass. We identified a thermal stability temperature equal to $209^{\circ} \mathrm{C}$ for the vulcanized natural rubber (NR). Using a similar 
Table 2 Surface roughness of the ferroelectric and magnetic nanocomposites as a function of the nanoparticle concentration

\begin{tabular}{llllllll}
\hline Sample & \multicolumn{6}{l}{ Surface roughness/nm } \\
\cline { 2 - 8 } & NR & $1 \mathrm{phr}$ & $3 \mathrm{phr}$ & $5 \mathrm{phr}$ & $10 \mathrm{phr}$ & $20 \mathrm{phr}$ & $50 \mathrm{phr}$ \\
\hline NR/KSN & 0.45 & 0.68 & 0.83 & 0.70 & 0.55 & 0.50 & 0.58 \\
NR/NZF & 0.45 & 0.50 & 0.63 & 0.55 & 0.45 & 0.43 & 0.45 \\
\hline
\end{tabular}

criterion, this value is approximately $80 \%$ higher than that published by Matthew et al. [22] for natural rubber and about $40 \%$ higher than the thermal stability temperature of silicone rubber studied by $\mathrm{Li}$ and et al. [23]. The maximum value of the thermal stability was $248{ }^{\circ} \mathrm{C}$ for the NR/NZF-
$50 \mathrm{phr}$, while the minimum value was $217{ }^{\circ} \mathrm{C} \mathrm{nm}$ for the NR/KSN-50 phr. The average thermal stability temperature for the $\mathrm{NR} / \mathrm{KSN}$ is equal to $223{ }^{\circ} \mathrm{C}$, approximately $11 \%$ higher than for the NR, and the average thermal stability temperature for the NR/NZF is equal to $232{ }^{\circ} \mathrm{C}$, about $8 \%$ higher than for NR. We suggested that the increase identified in the thermal stability temperature of the nanocomposites can mainly be associated to two factors: (1) an increase of the degree of cross-linking of the samples compared to the NR and (2) inserting a more thermally stable filler in the system, in this case ceramic nanoparticles. Interestingly, a decreasing peak can be identified in $3 \mathrm{phr}$ that can be ascribed to the stress-induced crystallization [24] that reduces the thermal stability (a)

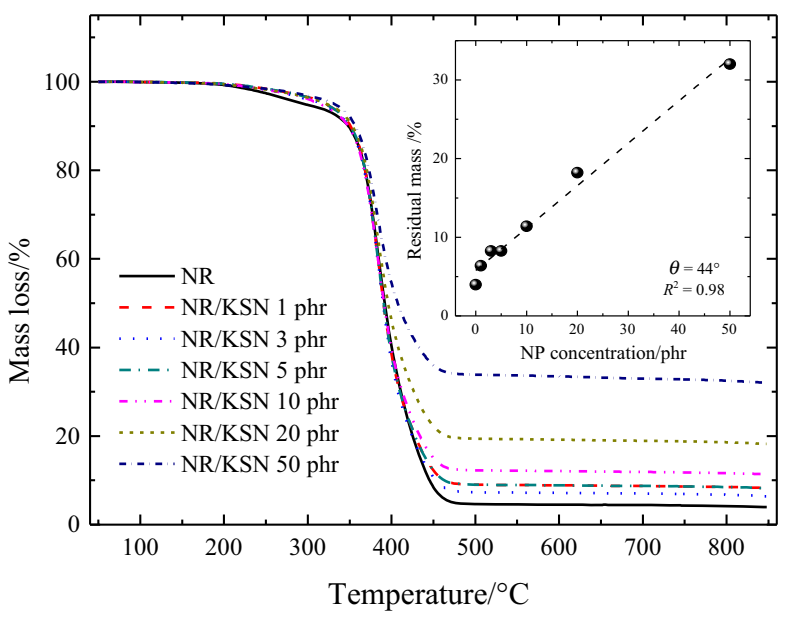

(c)

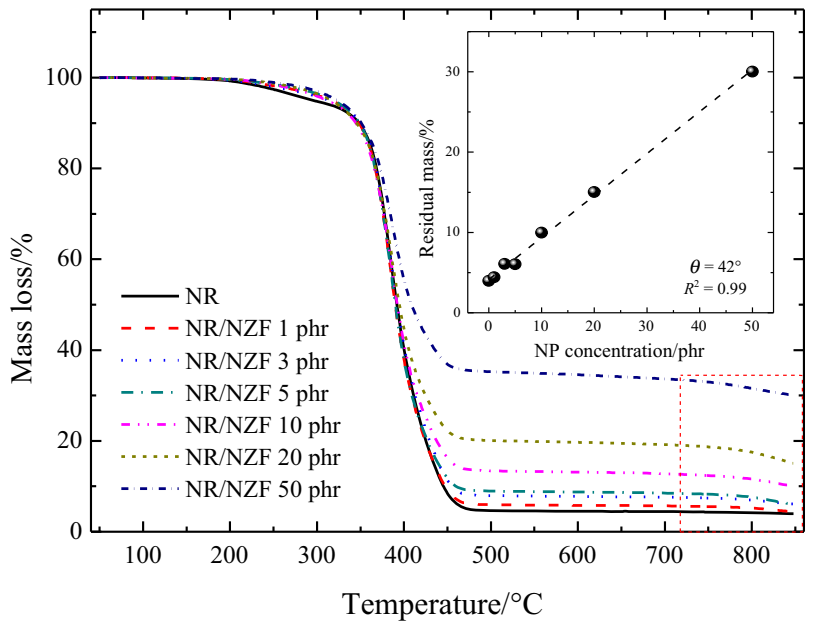

Fig. 3 Thermogravimetric (TG) and derivate thermogravimetric (DTG) analyses for the nanocomposites $\mathrm{NR} / \mathrm{KSN}(\mathbf{a}, \mathbf{b})$ and NR/ $\mathrm{NZF}(\mathbf{c}, \mathbf{d})]$ as a function of the concentration of nanoparticles. In (b)

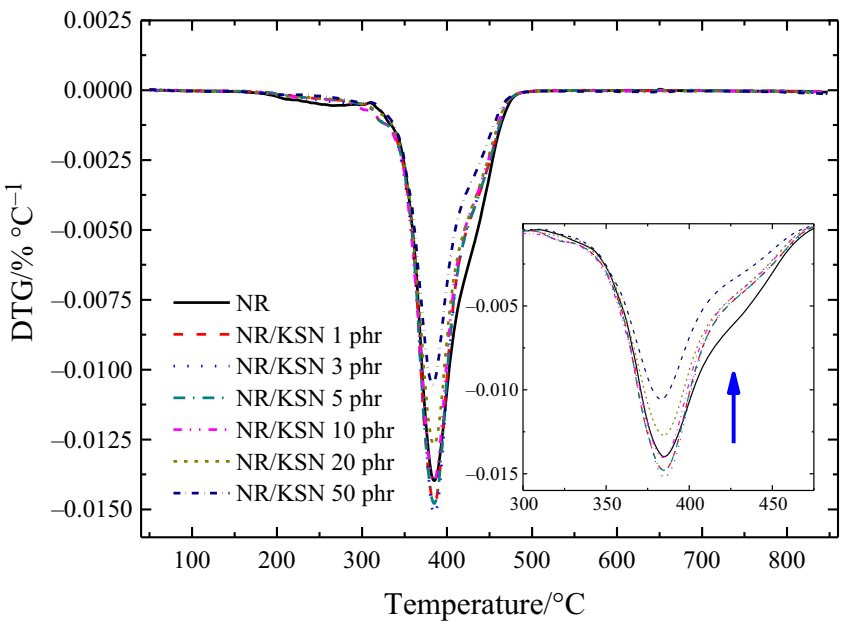

(d)

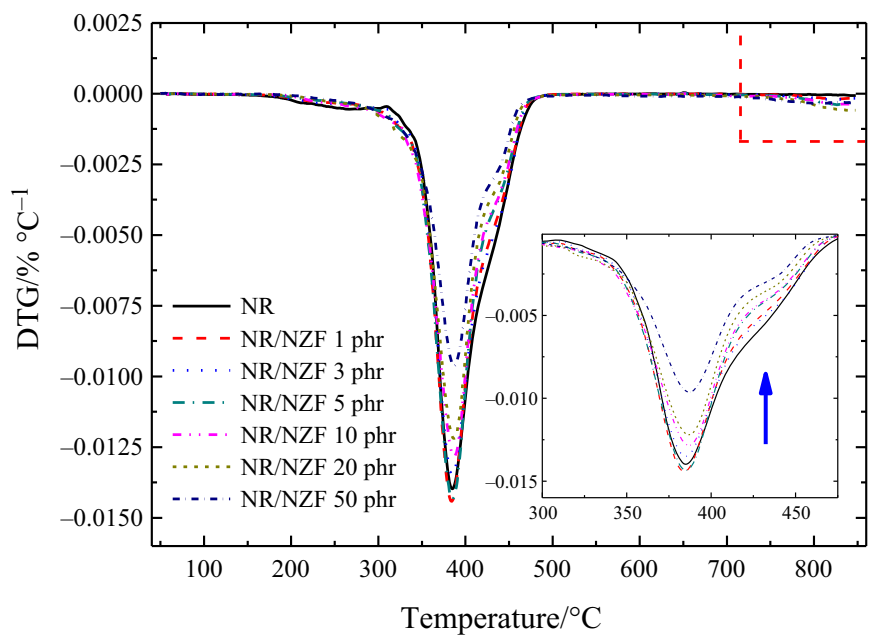

more detail, the percentage of residual mass for the nanocomposites at $850{ }^{\circ} \mathrm{C}(\mathbf{a}, \mathbf{c})$ and the region of $300-470{ }^{\circ} \mathrm{C}$ in the DTG analysis $(\mathbf{b}, \mathbf{d})$ 
Fig. 5 Thermogravimetry (TG) coupled to FTIR for the NR (a), NR/ KSN (b) and NR/NZF (c) nanocomposites. The concentration of nanoparticles utilized for nanocomposites was equal to $10 \mathrm{phr}$

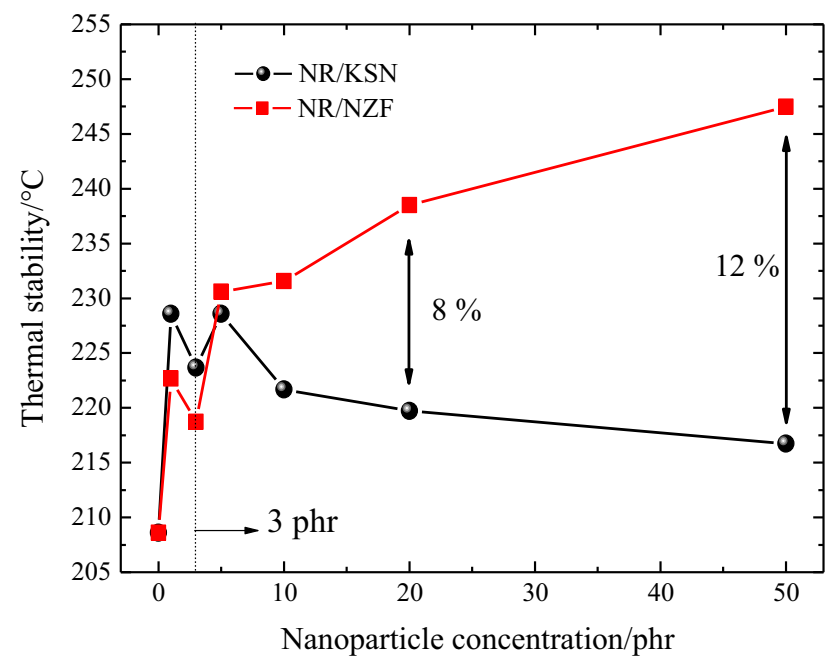

Fig. 4 Evolution of the thermal stability temperature as a function of nanoparticles concentration at magnetic (NR/NZF) and ferroelectric (NR/KSN) nanocomposites

temperature due to a localized, induced crystallization. Comparing the two kinds of nanocomposites with high concentrations (more than $20 \mathrm{phr}$ ), differences up to $12 \%$ in the $T_{\mathrm{S}}$ can be observed and attributed to distinct thermal conductivity and crystallity of the nanoparticles.

The TG technique is an extremely powerful thermal technique, but inherently quantitative and gives no direct chemical information. The ability to analyze the volatile products and decomposition mechanisms during a mass loss is of great value. Figure 5 shows the TG analysis coupled to FTIR for the NR (a), NR/KSN with $10 \mathrm{phr}$ (b) and NR/NZF with $10 \mathrm{phr}$ (c). As expected, all the spectra exhibit all of the vibration band characteristics of the poly(cis-1,4-isoprene) structure [25, 26]. It is possible to identify the presence of two main sets of bonds indicated by red arrows. The first set which is positioned at around 3000 with $2960 \mathrm{~cm}^{-1}$ has been assigned to a stretching band of C-H in a long carbon chain; at around 2913 and $2866 \mathrm{~cm}^{-1}$, the asymmetric and symmetric stretching of the methyl group $\left(\mathrm{CH}_{3}\right)$ was identified. The second set is positioned at around $1500 \mathrm{~cm}^{-1}$. The stretching band assigned to bond $\mathrm{C}=\mathrm{C}$ was identified at a frequency of $1534 \mathrm{~cm}^{-1}$, while the asymmetric and symmetric angular bending assigned to the methyl group $\left(\mathrm{CH}_{3}\right)$ are positioned in the region of 1442 and $1396 \mathrm{~cm}^{-1}$. For the NR/KSN and $\mathrm{NR} / \mathrm{NZF}$, bands of high intensity were identified at around (a)

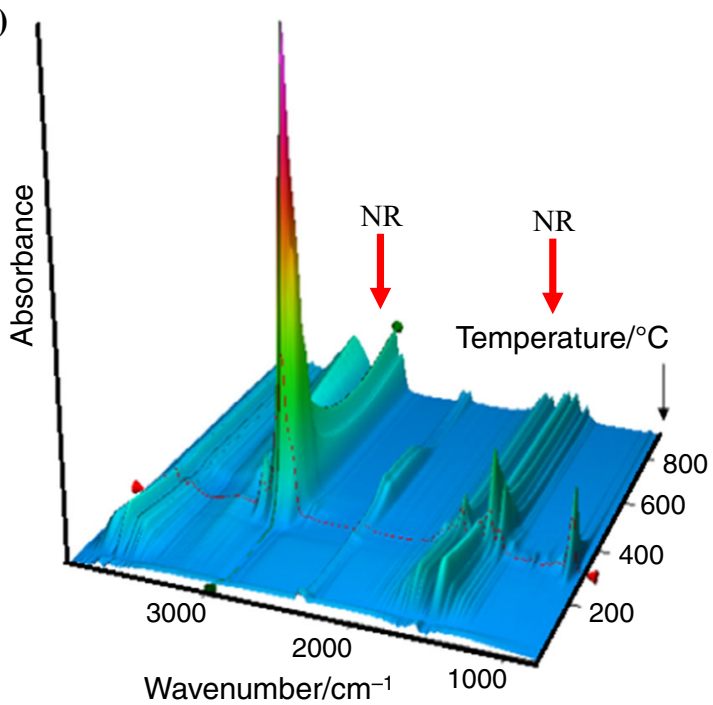

(b)

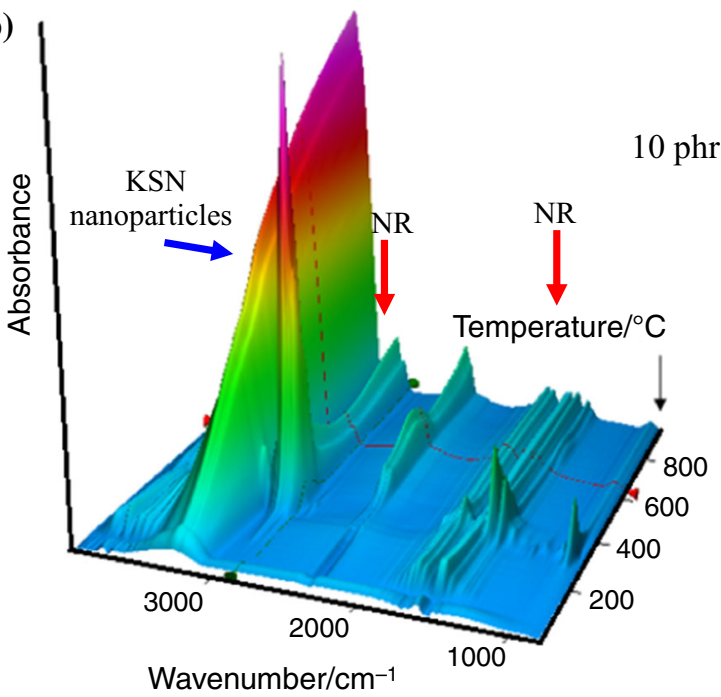

(c)

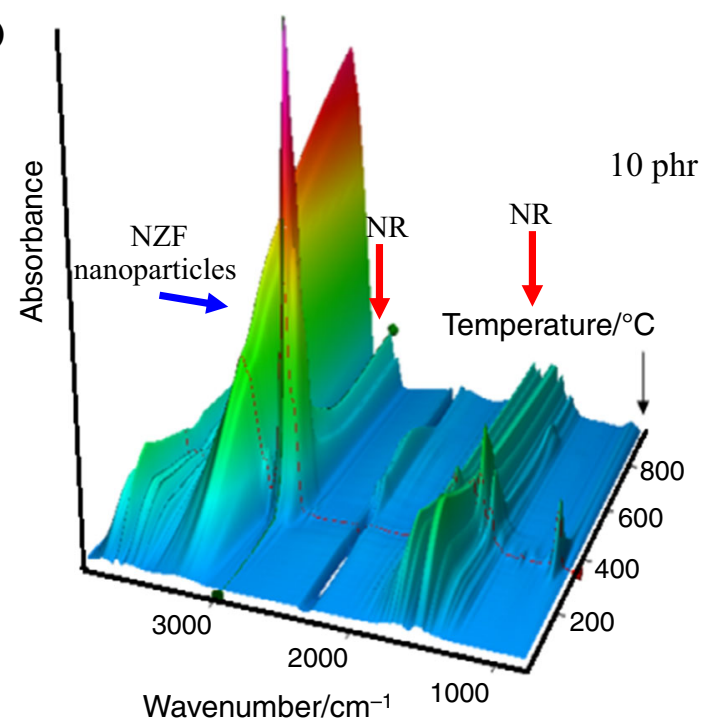



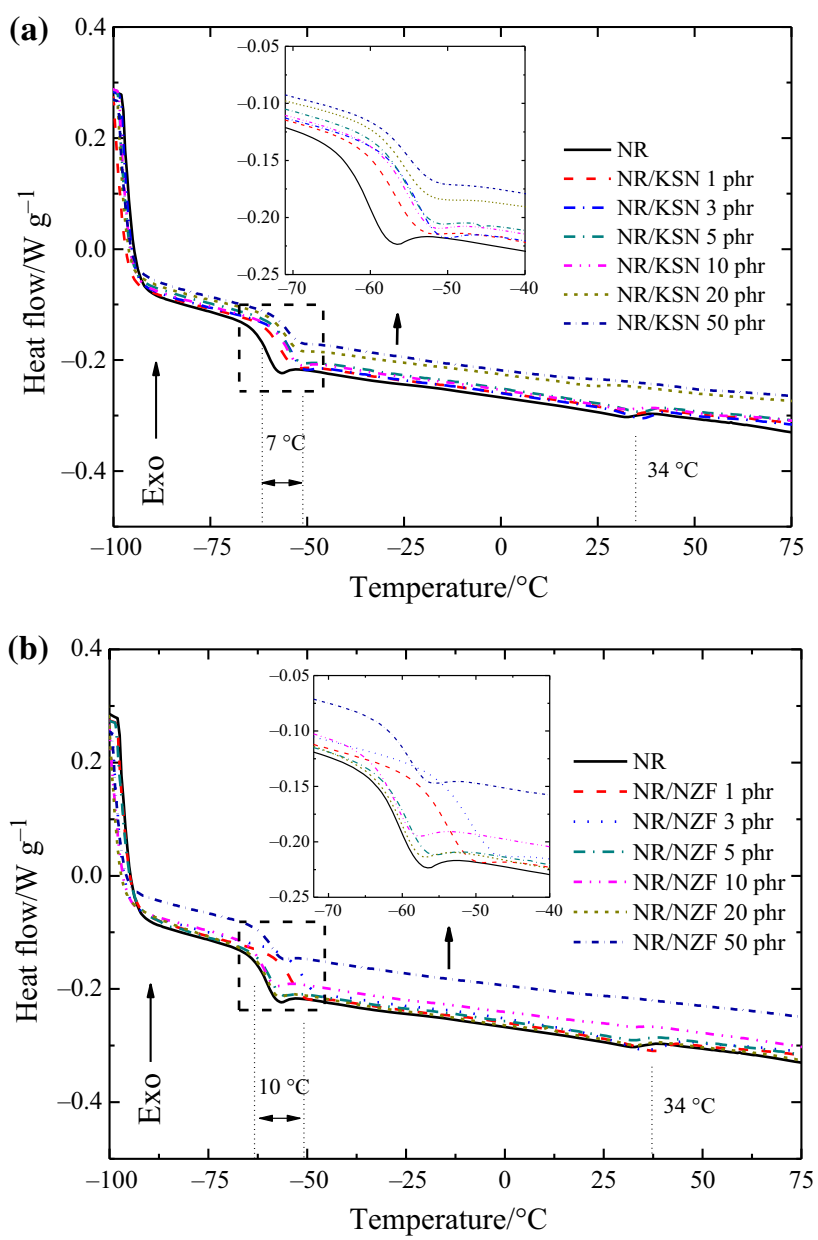

Fig. 6 DSC curves for the NR/KSN (a) and NR/NZF (b). Inside details of the glass transition reaction

$3300 \mathrm{~cm}^{-1}$, indicated by a blue arrow and correlated to the NZF and KSN nanoparticles, in specific, $\mathrm{O}-\mathrm{H}$ stretching vibrations present on the nanoparticle surface, phase transitions involving a variation of mass and organic materials originating from the chemical synthesis process of the nanoparticles.

Differential scanning calorimetry (DSC) is a technique widely used to determine the thermal transitions of polymeric materials such as fusion and crystallization events, oxidation reactions and the glass transition. Figure 6 shows DSC analysis for the NR/KSN (a) and NR/NZF (b). In Fig. 6, details of curves at around the temperature of glass transition can be observed. As can be seen, the DSC curves for the NR/KSN and NR/NZF have a development similar to the evolution of the temperature, which, in turn, resembles the evolution of the NR curve, indicating that the $T_{\mathrm{g}}$ parameter is independent or almost independent of the nanoparticle concentration. A discontinuity in the baseline with an exothermic character can be observed at around $-60{ }^{\circ} \mathrm{C}$ whose inflection point is attributed to the glass transition temperature $\left(T_{\mathrm{g}}\right)$ of the material. The glass transition is a physical phenomenon related to cooperative rearrangements, and in this case, a combination of molecular mobility degree, reticulation degree, intra and intermolecular interactions contributes to determine the magnitude of the $T_{\mathrm{g}}$ of material. The maximum value of $T_{\mathrm{g}}$ was $-50.7^{\circ} \mathrm{C}$ for the NR/NZF-3phr, while the minimum value was $-60.7{ }^{\circ} \mathrm{C} \mathrm{nm}$ for the NR/NZF-10phr. An exothermic reaction of low intensity was identified at around $34{ }^{\circ} \mathrm{C}$ at both NR/KSN and NR/NZF nanocomposites, suggesting that process is associated with desorption of water vapor and other volatile substances adsorbed on the nanocomposites' surface.

The glass transition is a kinetic phenomenon that is observed in amorphous or semicrystalline materials, and its origins come from the molecular mobility of cooperative units. Figure 7 a shows the evolution of the glass transition temperature $\left(T_{\mathrm{g}}\right)$ as a function of the concentration of nanoparticles. As a whole, nanocomposites exhibit a higher $T_{\mathrm{g}}$ than NR taking into account almost all the concentration of nanoparticles, indicating that slight changes are produced in the polymer matrix steaming nanoparticles addition. The changing of parameter $T_{\mathrm{g}}$ for $\mathrm{NR} / \mathrm{KSN}$ is equal to $7{ }^{\circ} \mathrm{C}$ and for NR/NZF is equal to $10^{\circ} \mathrm{C}$, as shown in Fig. 6a, b. Taking in account the $T_{\mathrm{g}}$ parameter, these changes suggest that parameters as intra and intermolecular interaction are more significant than the reticulation degree, since both intra and intermolecular interactions are enhanced by a set of parameters such as larger surface area and average crystallite size derived for the KSN nanopowders. In our previous research [14, 27], the dielectric characterization of the NR/KSN and NR/NZF nanocomposites was carried out, and their complex permittivity $\left[\varepsilon_{\mathrm{NC}} *(\omega)\right]$ could be written as a composition of two electroactive contributions: $\varepsilon_{\mathrm{NC}} *(\omega)=\varepsilon_{\mathrm{NC}}{ }^{\prime}(\omega)+$ $i \varepsilon_{\mathrm{NC}}{ }^{\prime \prime}(\omega)$. The first one, $\varepsilon_{\mathrm{NC}}{ }^{\prime}(\omega)$, is associated with the dielectric permittivity of nanocomposites, while the second one, $\varepsilon_{N C}{ }^{\prime \prime}(\omega)$, represents the dielectric loss of the nanocomposites. The evolution of the dielectric permittivity $\left(\varepsilon^{\prime}\right)$ of the NR/KSN and NR/NZF nanocomposites as a function of the nanoparticle concentration is shown in Fig. 7b. As can be seen, the dielectric permittivity, associated with the separation of electric charge, exhibited a rapid increment of its value with the insertion of the ceramic particles, independently of the nanoparticle type, achieving the maximum value for $\mathrm{NR} / \mathrm{KSN}, 8.2$, at concentration of $3 \mathrm{phr}$. After this increment, the permittivity returned to values close to the initial parameter and maintained itself at approximately constant values. We would like to highlight that a similar evolution was obtained for thermal stability (Fig. 4), the glass transition temperature (Fig. 7a) and dielectric permittivity (Fig. 7b), indicating that these phenomena are produced by the same mechanisms. In this case, mechanisms such as hydrogen 

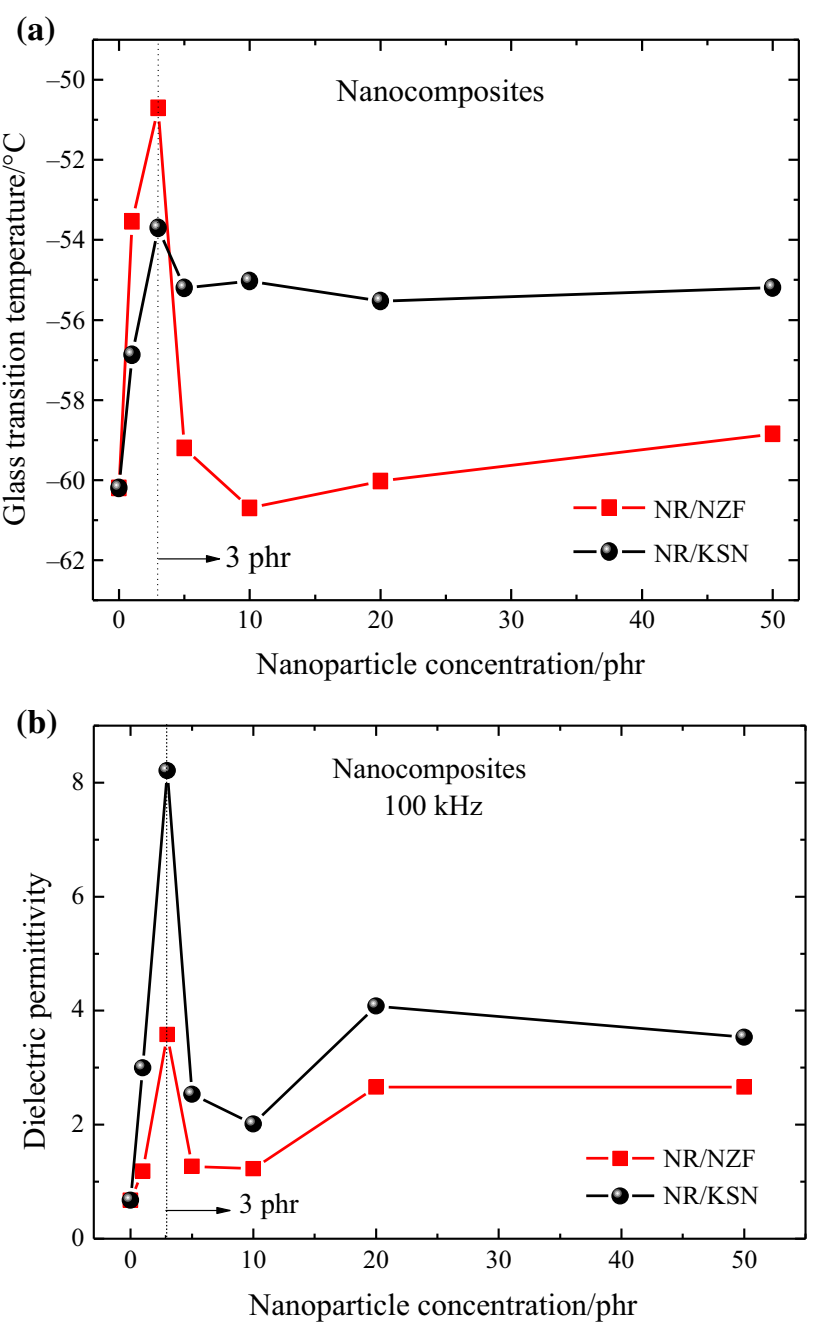

Fig. 7 Evolution of the glass transition temperature $\left(T_{\mathrm{g}}\right)(\mathbf{a})$ and dielectric permittivity $\left[\varepsilon_{\mathrm{NC}}{ }^{\prime}(\omega)\right]$ derived at $100 \mathrm{kHz}(\mathbf{b})$ as a function of nanoparticle concentration for the NR/KSN and NR/NZF nanocomposites

ions, electric dipoles, electron cloud oscillating on the nanoparticle surface and polymeric chain can also be considered [10].

\section{Conclusions}

Single-phase nanoparticles of paramagnetic or ferroelectric oxides were synthesized by a chemical route named the MPM. These nanoparticles were incorporated using a dry blend and also using different concentrations $(1,3,5,10$, 20 and $50 \mathrm{phr}$ ) in a natural rubber matrix to obtain magnetic and ferroelectric functional nanocomposites. The structural and morphological characterizations of the nanocomposites by AFM showed that a good surface homogeneity was obtained and different surface roughness for the NR, and both types of vulcanized natural rubber nanocomposites were investigated. The initial thermal studies revealed that the average thermal stability temperature for the NR, NR/KSN and NR/NZF nanocomposites was equal to $209,223{ }^{\circ} \mathrm{C}\left(7 \%\right.$ more than NR), and $232{ }^{\circ} \mathrm{C}$ (11\% more than NR), respectively. We suggested that the increase can be associated mainly with the increase in the degree of cross-linking and the inserting of a more thermally stable phase in the system (ceramic nanoparticles). They also revealed a significant variation in the $T_{\mathrm{g}}$ equal to $7{ }^{\circ} \mathrm{C}$ for the NR/KSN and $10{ }^{\circ} \mathrm{C}$ for the NR/NZF. In this specific case, we attributed this variation to a combination of molecular mobility degree, reticulation degree and intra and intermolecular interactions. Comparing the parameter evolution of the glass transition temperature, dielectric permittivity and thermal stability temperature, a similar behavior was identified, indicating that these phenomena are predominantly dominated by the same mechanisms.

Acknowledgements The authors acknowledge the Brazilian research agencies FAPESP (No. 2009/00523-8), CAPES (Nos. BEX 5129/09-5 and 11208/13-9), CNPq (Nos. 480377/2013-8, 455323/2014-and 454843/2014-3) and FEPISA (No. 010/2014) for their financial support.

\section{References}

1. Lanfredi S, Darie C, Bellucci FS, Colin CV, Nobre MAL. Phase transitions and interface phenomena at cryogenic temperature domain of a niobate nanostructured ceramic. Dalton Trans. 2014;43:10983-98.

2. Schexnailder P, Schmidt G. Nanocomposite polymer hydrogels. Colloid Polym Sci. 2009;287:1.

3. Rekosova J, Dosoudil R, Usakova M, Usak E, Hudec I. Magnetopolymer composites with soft magnetic ferrite filler. IEEE Trans Magn. 2013;49:1.

4. Jang J, Inoue $Y$, Iwasa M, Yoshida H. Nanoparticle distribution in NR/BR blend. J Therm Anal Calorim. 2016;123:1841-6.

5. Simoes RD, Job AE, Chinaglia DL, Zucolotto V, Camargo JC, Alves N, Giacometti JA, Oliveira ON, Constantino CJL. Structural characterization of blends containing both PVDF and natural rubber latex. J Raman Spectrosc. 2005;36:1118.

6. Ioannou G, Patsidis A, Psarras GC. Dielectric and functional properties of polymer matrix/ZnO/BaTiO 3 hybrid composites. Compos A. 2011;42:104-10.

7. Xu Q, Yao Y, Ma Z, Xia Z. Measurement of interfacial energy and friction between carbon nanotubes and polymer matrix by a micro-pullout test. Sci Adv Mater. 2012;4:888.

8. Matchawet S, Kaesaman A, Bomlai P, Nakason C. Electrical, dielectric, and dynamic mechanical properties of conductive carbon black/epoxidized natural rubber composites. J Compos Mater. 2015. doi:10.1177/0021998315602941.

9. Sunny V, Kurian P, Mohanan P, Joy PA, Anantharaman MR. A flexible microwave absorber based on nickel ferrite nanocomposite. J Alloys Compd. 2010;489:297.

10. Queiroz RM, Coelho TL, Queiroz IM, Pires LHO, Santos IMG, Zamian JR, Rocha Filho GN, Costa CEF. Structural and thermal characterization of $\mathrm{Ni}_{\mathrm{x}} \mathrm{Zn}_{1-\mathrm{x}} \mathrm{Al}_{2} \mathrm{O}_{4}$ synthesized by the polymeric precursor method. J Therm Anal Calorim. 2016;124:1023-8. 
11. Dursun S, Alkoy S. Processing, structural and electrical properties of textured potassium strontium niobate $\left(\mathrm{KSr}_{2} \mathrm{Nb}_{5} \mathrm{O}_{15}\right)$ piezoceramic fibers. Adv Mater Res. 2012;445:481.

12. Rotaru A, Schiemer JA, Carpenter MA. Elastic and anelastic relaxations accompanying relaxor ferroelectric behaviour of $\mathrm{Ba}_{6} \mathrm{GaNb}_{9} \mathrm{O}_{30}$ tetragonal tungsten bronze from resonant ultrasound spectroscopy. J Therm Anal Calorim. 2016;124:571-83.

13. Nasir S, Anis-Ur-rehman M. Structural, electrical and magnetic studies of nickel-zinc nanoferrites prepared by simplified sol-gel and co-precipitation methods. Phys Scr. 2011;84:025603.

14. Bellucci FS. Preparation and characterization of multifunctional nanocomposites obtained with ferroelectric and paramagnetic nanoparticles in natural rubber films. 2013. 185 s. Thesis (Doctor in Science and Technology of Materials and Physics Science)UNESP and UVa, Presidente Prudente. 2013.

15. Bellucci FS, Budemberg ER, Nobre MAL, de Saja JA, Aroca RF, Rodriguez-Perez MA, Job AE. Mechanical properties of vulcanized natural rubber nanocomposites containing functional ceramic nanoparticles. Sci Adv Mater. 2013;5:637-46.

16. Bellucci FS, Almeida FCL, Nobre MAL, Rodriguez-Perez MA, Paschoalini AT, Job AE. Magnetic properties of vulcanized natural rubber nanocomposites as a function of the concentration, size and shape of the magnetic fillers. Compos Part B Eng. 2016;85:196-206.

17. Daigle A, Modest J, Geiler AL, Gillette S, Chen Y, Geiler M, Hu B, Kim S, Stopher K, Vittoria C, Harris VG. Structure, morphology and magnetic properties of $\mathrm{Mg}_{(\mathrm{x})} \mathrm{Zn}_{(1-\mathrm{x})} \mathrm{Fe}_{2} \mathrm{O}_{4}$ ferrites prepared by polyol and aqueous co-precipitation methods: a lowtoxicity alternative to $\mathrm{Ni}_{(\mathrm{x})} \mathrm{Zn}_{(1-\mathrm{x})} \mathrm{Fe}_{2} \mathrm{O}_{4}$ ferrites. Nanotechnology. 2011;22:305708.

18. Bellucci FS, Salmazo LO, Budemberg ER, Nobre MAL, Job AE. Production method of functional nanocomposites and obtained products. Patent Process. BR102012005278-4; 2012.
19. Ozbas B, Toki S, Hsiao BS, Chu B, Register RA, Aksay IA, Prud'homme RK, Adamson DH. Strain-induced crystallization and mechanical properties of functionalized graphene sheet-filled natural rubber. J Polym Sci, Part B: Polym Phys. 2012;50:718.

20. Uskokovic V, Drofenik M, Ban I. The characterization of nanosized nickel-zinc ferrites synthesized within reverse micelles of $\mathrm{CTAB} / 1$-hexanol/water microemulsion. J Magn Magn Mater. 2004;284:294.

21. Ray HS, Kundu N. Thermal analysis studies on the initial stages of iron oxide reduction. Thermochim Acta. 1986;101:107.

22. Mathew AP, Packirisamy S, Thomas S. Studies on the thermal stability of natural rubber/polystyrene interpenetrating polymer networks: thermogravimetric analysis. Polym Degrad Stabil. 2001;72:423.

23. Li Z, et al. Metal catalyst residues in carbon nanotubes decrease the thermal stability of carbon nanotube/silicone composites. Carbon. 2011;49:4138.

24. Trabelsi S, et al. Stress-induced crystallization around a crack tip in natural rubber. Macromolecules. 2002;35:10054.

25. Lotti C, Moreno RMB, Gonçalves PS, Bhattacharya S, Mattoso LHC. Extensional rheology of raw natural rubber from new clones of Hevea brasiliensis. J Polym Eng Sci. 2012;52:139.

26. Agostini DLS, Constantino CJL, Job AE. Thermal degradation of both latex and latex and cast films forming membranes. J Therm Anal Calorim. 2008;91:703.

27. Silvania L, Palacio G, Bellucci FS, Colin CV, Nobre MAL. Thermistor behavior and electric conduction analysis of Ni-doped niobate ferroelectric: the role of multiples beta parameters. J Phys D Appl Phys. 2012;45:435302. 